\title{
Primary hyperoxaluria type 1: a cluster of new mutations in exon 7 of the AGXT gene
}

\author{
C von Schnakenburg, G Rumsby
}

\begin{abstract}
Primary hyperoxaluria type 1 (PH1) is a severe autosomal recessive inborn error of glyoxylate metabolism caused by deficiency of the hepatic peroxisomal enzyme alanine:glyoxylate aminotransferase. This enzyme is encoded by the AGXT gene on chromosome 2q37.3. DNA samples from 79 PH1 patients were studied using single strand conformation polymorphism analysis to detect sequence variants, which were then characterised by direct sequencing and confirmed by restriction enzyme digestion. Four novel mutations were identified in exon 7 of AGXT: a point mutation T853C, which leads to a predicted Ile244Thr amino acid substitution, occurred in nine patients. Two other mutations in adjacent nucleotides, C819T and G820A, mutated the same codon at residue 233 from arginine to cysteine and histidine, respectively. The fourth mutation, G860A, introduced a stop codon at amino acid residue 246. Enzyme studies in these patients showed that AGT catalytic activity was either very low or absent and that little or no immunoreactive protein was present. Together with a new polymorphism in exon 11 (C1342A) these findings underline the genetic heterogeneity of the AGXT gene. The novel mutation T853C is the second most common mutation found to date with an allelic frequency of $9 \%$ and will therefore be of clinical importance for the diagnosis of PH1.
\end{abstract}

$(\mathcal{F}$ Med Genet 1997;34:489-492)

Keywords: primary hyperoxaluria type 1; AGXT; SSCP

Primary hyperoxaluria type 1 (PH1, McKusick 259900 ) is a rare autosomal recessive inborn error of glyoxylate metabolism characterised biochemically by increased synthesis and excretion of oxalate and in most cases glycolate. The metabolic changes are caused by a deficiency of the pyridoxine dependent, hepatic peroxisomal enzyme alanine:glyoxylate aminotransferase (AGT, EC 2.6.1.44), ${ }^{1}$ which is encoded by a single copy gene (AGXT) on chromosome $2 \mathrm{q} 37.3 .^{2}$

PH1 is a heterogeneous disorder covering a wide range of clinical and biochemical phenotypes. ${ }^{3}$ Affected subjects may present with recurrent calcium oxalate urolithiasis, nephrocalcinosis, renal failure, or systemic oxalosis at all ages. ${ }^{4}$ Treatment ranges from supportive management with pyridoxine therapy in responsive cases to renal and hepatic transplantation, the latter offering a curative approach by replacing the deficient enzyme. ${ }^{5}$

Studies of liver biopsies showed three main enzymic phenotypes: $35 \%$ of $\mathrm{PH} 1$ patients lack both AGT catalytic activity and immunoreactivity, $24 \%$ have immunoreactive AGT without catalytic activity, and the remaining $41 \%$ of PH1 patients exhibit immunoreactive protein and some AGT activity in vitro. In a significant number of the latter group, the enzyme is mistargeted from peroxisomes to mitochondria. ${ }^{6}$

The AGXT gene, which encodes the 392 amino acid protein AGT, has been sequenced and mapped to chromosome $2 \mathrm{q} 37.3 .^{2}$ It consists of 11 exons spanning about $10 \mathrm{~kb}$. So far, four polymorphisms ${ }^{7-9}$ and seven mutations have been described in this gene..$^{78^{10-13}}$ The most frequent mutation (G630A) is characterised by the mitochondrial mistargeting of $\mathrm{AGT}^{7}$ when found in the presence of the polymorphic "minor" allele, which is a combination of two single nucleotide changes, C154T, A1142G, a 74 bp insertion in intron 1, and a variable number tandem repeat in intron $4 .^{\circ}$ G630A occurs in about $25 \%$ of PH1 alleles, the remaining six mutations accounting for a further $4 \%$ of alleles in our series of $79 \mathrm{PH} 1$ patients (A C Tarn, C von Schnakenburg, G Rumsby, manuscript submitted), thus leaving a large number of alleles without any known mutation detected. In order better to define the nature of this disease and the relationship of the coding regions to protein product, we have initiated a systematic search for further mutations in the AGXT gene.

\section{Materials and methods} PATIENTS

EDTA blood samples of 79 unrelated patients with $\mathrm{PH} 1$ were available following referral to the University College London Hospital Primary Hyperoxaluria Service. All patients or their parents consented to DNA studies being performed. A wide variety of nationalities and ethnic groups was represented. Diagnosis of PH1 was based on measurement of AGT catalytic activity and immunoreactivity in liver biopsies $(78 \%)$ or urine analysis (raised oxalate and glycolate) in combination with clinical symptoms (urolithiasis, nephrocalcinosis, end stage renal failure). All 79 samples had been screened for four polymorphisms (C154T, A1142G, a 74 bp insertion in intron 1 , and a variable number tandem repeat in intron $4^{7-9}$ ) and seven known mutations (G243A, C320G, G367A, T576A, G630A, C682T, and

\author{
Received 4 December 1996 \\ Revised version accepted for \\ publication 4 February 1997 \\ Molecular Pathology, \\ Windeyer Building \\ London W1P 6DB, UK \\ G Rumsby \\ Correspondence to: \\ Dr Rumsby.
}


Table 1 Details of primers and PCR conditions for amplification of DNA. Exon 11 was examined in two overlapping fragments $(A+B)$. Adding $10 \%$ DMSO improved yield and purity of the PCR product in exon $11 \mathrm{~A}$

\begin{tabular}{|c|c|c|c|c|}
\hline $\begin{array}{l}\text { Region } \\
\text { amplified }\end{array}$ & Primer pair & $\begin{array}{l}\text { Product size } \\
(b p)\end{array}$ & $\begin{array}{l}\mathrm{MgCl}_{2} \\
\left(\mathrm{mmol.} t^{-1}\right)\end{array}$ & $\begin{array}{l}\text { Annealing } \\
\text { temperature } \\
\left({ }^{\circ} \mathrm{C}\right)\end{array}$ \\
\hline Exon 1 & $\begin{array}{l}\text { 5'GCACAGATAAGCCTCAGGGA } \\
\text { 5'ATCTGTGGGTGGGAACATGG }\end{array}$ & 382 & 1.5 & 62 \\
\hline Exon 2 & $\begin{array}{l}\text { 5'TGGGTCTCACCCTATACCAC } \\
\text { 5'CTTGAAGGATGGATCCAGGG }\end{array}$ & 270 & 1.5 & 58 \\
\hline Exon 3 & $\begin{array}{l}\text { 5'CCAACGGGTGCCCAACACTG } \\
\text { 5'ATTCCAGGCAGCCCCTGAGC }\end{array}$ & 211 & 1 & 66 \\
\hline Exon 4 & $\begin{array}{l}\text { 5'CCCTCTGAGCTCCACCCACA } \\
\text { 5'TCTGAGCTGAGCTCCAGTCC }\end{array}$ & 181 & 0.8 & 64 \\
\hline Exon 5 & $\begin{array}{l}\text { 5'CCGAATTCGCAGCATCGGCT } \\
\text { 5'CACCTGCAGCCCTCCATTCT }\end{array}$ & 215 & 1.5 & 60 \\
\hline Exon 6 & $\begin{array}{l}\text { 5'TAGGCAGGCATCCCGCTGGA } \\
\text { 5'CACCTGAGCTCCCTGCAAGC }\end{array}$ & 218 & 1.5 & 60 \\
\hline Exon 7 & $\begin{array}{l}\text { 5'CCGTCTCACTCCCGTGAAAC } \\
\text { 5'CACCTGTCAGCCATGCCCAG }\end{array}$ & 246 & 1.5 & 62 \\
\hline Exon 8 & $\begin{array}{l}\text { 5'CAGACAGAGCTCATGCCCCA } \\
\text { 5'GCGTCGACAATCCAGCCAGT }\end{array}$ & 257 & 1 & 62 \\
\hline Exon 9 & $\begin{array}{l}\text { 5'TTCTTCCTCCAGCACCACAG } \\
\text { 5'GCAAGAGCCCCTCATCCTCC }\end{array}$ & 239 & 1.5 & 62 \\
\hline Exon 10 & $\begin{array}{l}\text { 5'AGCTGTCACAAAGCCCGTAC } \\
\text { 5'CCTGGTGCACAGTCCTGCTC }\end{array}$ & 266 & 0.8 & 62 \\
\hline Exon 11A & $\begin{array}{l}\text { 5'TCACTCAGGTGAGCCCATCC } \\
\text { 5'TGGAGGACCTTGCAGGGTCT }\end{array}$ & 298 & 1 & 60 \\
\hline Exon 11B & $\begin{array}{l}\text { 5'TGGCACACACCTGTCCCATG } \\
\text { 5'ACTCTTTCACAGACCACCCC }\end{array}$ & 298 & 1 & 63 \\
\hline
\end{tabular}

T735C ${ }^{810-13}$ (A C Tarn, C von Schnakenburg, G Rumsby, manuscript submitted)).

DNA from 50 normal controls was extracted from anonymous EDTA samples received in our Haematology Department during one day.

POLYMERASE CHAIN REACTION (PCR)

DNA was isolated from EDTA whole blood as previously described ${ }^{14}$ and stored at $-20^{\circ} \mathrm{C}$ before analysis. Primers were designed according to the published genomic sequence of AGXT (EMBL/Genbank accession numbers M61755-M61763 and M61833, ${ }^{2}$ further unpublished sequence was kindly provided by $\mathrm{Dr}$ C J Danpure, University College, London). The PCR reaction mixtures contained 2-5 $\mu$ l DNA (approximately $80-200 \mathrm{ng}$ ), $0.2 \mathrm{mmol}^{-\mathrm{l}^{-1}}$ dNTPs, $1 \mu \mathrm{mol} .1^{-1}$ each oligonucleotide primer (Oswell, Southampton, UK), and 0.25 U Taq polymerase in reaction buffer (Promega, Southampton, UK) in a final volume of $25 \mu \mathrm{l}$. Primer sequences, magnesium concentrations, and annealing temperatures for the reactions are provided in table 1 . Amplification conditions were 35 cycles at $94^{\circ} \mathrm{C}$, at the stated annealing temperature and at $72^{\circ} \mathrm{C}$ for 0.5 minutes each on a thermal cycler (Hybaid, Teddington, UK). Purity and size of the PCR products were checked on a $2 \%$ agarose gel using standard electrophoresis methods.

SINGLE STRAND CONFORMATION POLYMORPHISM (SSCP) ANALYSIS

Two $\mu$ l PCR product was added to $4 \mu$ of a $7: 5$ mix of formamide dye solution $(95 \%$ formamide, 10 mmol..$^{-1}$ EDTA, $0.05 \%$ bromophenol blue, $0.05 \%$ xylene cyanol $\mathrm{FF}$ ) and $0.1 \%$ SDS containing $10 \mathrm{mmol}^{-1} \mathrm{l}^{-1}$ EDTA. ${ }^{15}$ DNA was denatured at $90^{\circ} \mathrm{C}$ for five minutes and chilled immediately on iced water before being loaded onto a $10 \%$ polyacrylamide gel (CleanGel, Pharmacia, St Albans, UK). Separation was performed on a Multiphor II electrophoresis unit at $15^{\circ} \mathrm{C}$ according to the manufacturer's instructions followed by silver staining (Pharmacia).

DNA SEQUENCE ANALYSIS

Samples for DNA sequencing according to the modified Sanger dideoxy method ${ }^{16}$ were purified using Geneclean (Bio101, supplied by Anachem, Luton, UK). A thermocycle reaction was carried out with a Texas Red labelled forward primer for exon 7 and exon 11A (Oswell) and a premixed Vistra Thermo Sequenase Kit (Amersham International, Little Chalfont, UK) following the instructions of the supplier. DNA sequences were detected and analysed on an automated Vistra DNA Sequencer 725 (Amersham International).

RESTRICTION DIGESTS

Five $\mu$ l of PCR product were incubated with 5 $\mathrm{U}$ of restriction endonuclease (table 2 and $R s a \mathrm{I}$ for exon 11) in the appropriate $1 \times$ buffer and temperature overnight. Fragments were separated by electrophoresis on $2 \%$ agarose gels.

AGT ACTIVITY AND IMMUNOREACTIVITY

Liver biopsies from $\mathrm{PH} 1$ patients were analysed for AGT activity and immunoreactivity as described previously. ${ }^{17}$

\section{Results}

SSCP analysis under the stated conditions detected all previously described polymorphisms and mutations with the exception of G243A in exon 1 (two samples), T735C in exon 6 (one sample), and G367A in exon 2 (positive control). No attempt was made to increase the sensitivity by changing reaction conditions (temperature or product size).

New SSCP patterns were identified in exon 11 (36 samples), exon 7 (12 samples), exon 5 (three samples), exon 2 and exon 8 (two samples each), exon 4, exon 9, and exon 10 (one sample each).

Direct sequencing of samples with a new SSCP pattern in exon 11 identified a nucleotide change at position 1342 from $\mathrm{C}$ to $\mathrm{A}$ which creates a $R s a \mathrm{I}$ restriction site. Twelve subjects (15\%) were homozygous and 24 $(30 \%)$ heterozygous for this transversion. A similar distribution of this C1342A polymorphism was found in 50 normal controls (12\% homozygotes, $42 \%$ heterozygotes). This polymorphism does not affect the predicted AGT coding sequence, lying 41 nucleotides downstream of the stop codon in the $3^{\prime}$ untranslated region.

Four sequence variants were identified in exon 7 of the AGXT gene by SSCP analysis The patterns obtained from normal sequences and these variants are shown in fig 1 . Nine of 79 patients' samples showed pattern 1 and a further three showed patterns 2,3 , and 4 respectively.

The sequence changes were identified by direct sequencing of PCR products and are given in table 2 . A point mutation, T853C, was shown to be responsible for SSCP pattern 1 . Patterns 2, 3, and 4 were caused by nucleotide substitutions C819T, G820A, and G860A, respectively. All mutations either introduced or 


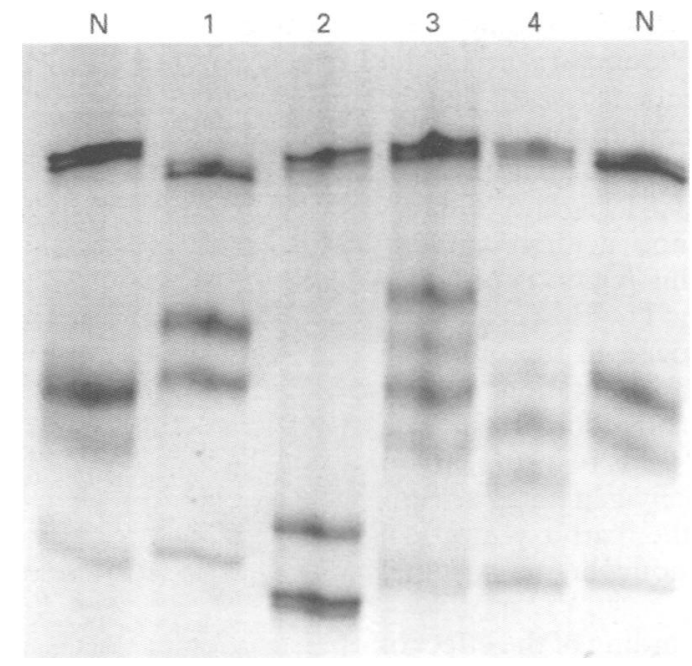

Figure 1 SSCP patterns for exon 7 of the AGXT gene in two normal controls (N) and four $P H 1$ patients showing SSCP patterns 1-4, respectively.

deleted a restriction enzyme site and were confirmed by restriction digestion of amplified DNA (table 2). Family studies were carried out in two unrelated patients homozygous for T853C (patients A and B in table 2) and confirmed that the parents were heterozygous for the mutation, while a sib of patient $B$, also with $\mathrm{PH} 1$, was homozygous for the mutation. Two patients heterozygous for T853C (patients $\mathrm{H}$ and $\mathrm{K}$ ) and one patient heterozygous for G860A (patient $N$ ) were also heterozygous for the G630A mutation in exon 4 and thus are presumed compound heterozygotes. None of the other six previously described mutations was detected in these 12 cases. The novel point mutation T853C identified in nine PH1 patients leads to a predicted Ile244Thr amino acid substitution, while C819T and G820A introduce the missense mutations Arg233Cys and Arg233His, respectively, and G860A inserts a stop codon at Trp246. None of these mutations was identified in 50 normal controls by SSCP analysis.
Enzyme studies were performed in liver biopsies from 11 of 12 patients with mutations in exon 7 and showed that AGT catalytic activity was either very low or absent and little or no immunoreactive protein was present (table 2).

DNA sequence changes responsible for the different SSCP pattern in exons $2,4,5,8$, and 9 (10 patients in all) have yet to be determined.

\section{Discussion}

SSCP has proved to be a suitable means to detect mutations by mobility shift of single stranded DNA with an empirical sensitivity of approximately $90 \%$ in small DNA fragments. ${ }^{18}$ We screened all 11 exons of the AGXT gene and detected a cluster of new mutations in exon 7 and a new polymorphism in exon 11 in addition to known variants and some rare patterns.

The missense mutation T853C in exon 7 was found in nine of $79 \mathrm{PH} 1$ patients and a further affected sib. With an allelic frequency of $9 \%$ this is the second most common mutation after G630A. Therefore, it is of great significance for our understanding of this disease.

The segregation of the T853C mutation with disease in one family supports the causal role of this mutation in PH1. The finding of three other mutations in the same exon with similar enzymic characteristics, namely very little catalytic activity and only a small amount of immunoreactive protein present, is further proof of the importance of this gene region in enzyme or mRNA stability.

Our knowledge about the structure-function relationship of the human AGXT gene to the AGT protein is mainly limited to sequences which determine the intracellular location of the enzyme: a weak mitochondrial targeting sequence is present at the amino-terminal end of the protein in those people carrying a Pro11Leu polymorphism ${ }^{7}$ and a peroxisomal targeting sequence has been identified at the C-terminal end of the enzyme. ${ }^{19}$ The putative pyridoxine binding site has been located at residue Lys $209^{20}$ and an evolutionarily highly

Table 2 Details of biochemical and genetic analyses in 12 unrelated PH1 patients with mutations in exon 7 of the AGXT gene

\begin{tabular}{|c|c|c|c|c|c|c|c|c|}
\hline Patient & $\begin{array}{l}\text { SSCP } \\
\text { pattern }\end{array}$ & Exon 7 mutation & $\begin{array}{l}\text { Restriction } \\
\text { site }\end{array}$ & $\begin{array}{l}\text { Amino acid } \\
\text { change }\end{array}$ & $\begin{array}{l}\text { Minor allele } \\
\text { polymorphism }\end{array}$ & $\begin{array}{l}\text { Other mutations or } \\
\text { polymorphisms detected }\end{array}$ & $\begin{array}{l}\text { AGT catalytic } \\
\text { activity }(\% \text { of } \\
\left.\text { normal activity }{ }^{17}\right)\end{array}$ & $\begin{array}{l}\text { Immunoreactive protein } \\
\text { (semiquantitive comparison } \\
\text { to normal liver } \\
\text { (I) }\end{array}$ \\
\hline A & 1 & $\begin{array}{l}\text { Homozygous } \\
\text { T853C }\end{array}$ & Bst XI & Ile244Thr & Homozygous & None & 14 & Weak positive \\
\hline B & 1 & $\begin{array}{l}\text { Homozygous } \\
\text { T853C }\end{array}$ & $B s t \mathrm{XI}$ & Ile244Thr & Homozygous & None & 0 & Weak positive \\
\hline $\mathrm{C}$ & 1 & $\begin{array}{l}\text { Homozygous } \\
\text { T853C }\end{array}$ & $B s t \mathrm{XI}$ & Ile244Thr & Homozygous & None & 12 & Weak positive \\
\hline $\mathrm{D}$ & 1 & $\begin{array}{l}\text { Homozygous } \\
\text { T853C }\end{array}$ & $B s t \mathrm{XI}$ & Ile244Thr & Homozygous & None & 7 & Weak positive \\
\hline $\mathrm{E}$ & 1 & $\begin{array}{l}\text { Homozygous } \\
\text { T853C }\end{array}$ & $B s t \mathrm{XI}$ & Ile244Thr & Homozygous & None & 11 & Weak positive \\
\hline F & 1 & $\begin{array}{l}\text { Heterozygous } \\
\text { T853C }\end{array}$ & $B s t \mathrm{XI}$ & Ile244Thr & Heterozygous & Heterozygous $\mathrm{C} 1342 \mathrm{~A}$ & 0 & Negative \\
\hline G & 1 & $\begin{array}{l}\text { Heterozygous } \\
\text { T853C }\end{array}$ & Bst XI & Ile244Thr & Heterozygous & $\begin{array}{l}\text { Unidentified mutation in } \\
\text { exon } 2\end{array}$ & 11 & Weak positive \\
\hline $\mathrm{H}$ & 1 & $\begin{array}{l}\text { Heterozygous } \\
\text { T853C }\end{array}$ & Bst XI & Ile244 Thr & Homozygous & Heterozygous G630A & 0 & Weak positive \\
\hline $\mathrm{K}$ & 1 & $\begin{array}{l}\text { Heterozygous } \\
\text { T853C }\end{array}$ & $B s t \mathrm{XI}$ & Ile244Thr & Homozygous & Heterozygous G630A & 11 & Weak positive \\
\hline L & 2 & $\begin{array}{l}\text { Homozygous } \\
\text { C819T }\end{array}$ & $A c i \mathrm{I}$ & Arg233Cys & Homozygous & None & Unknown & Unknown \\
\hline M & 3 & $\begin{array}{l}\text { Heterozygous } \\
\text { G820A }\end{array}$ & $A c \imath \mathrm{I}$ & $\operatorname{Arg} 233 \mathrm{His}$ & Heterozygous & Heterozygous C1342A & 0 & Negative \\
\hline $\mathbf{N}$ & 4 & $\begin{array}{l}\text { Heterozygous } \\
\text { G860A }\end{array}$ & MaeIII & Trp246Stop & Heterozygous & $\begin{array}{l}\text { Heterozygous G630A and } \\
\text { C1342A }\end{array}$ & 0 & Weak positive \\
\hline
\end{tabular}


conserved region of AGXT exists between residues 133 and $190 .{ }^{21}$ Comparison of the human AGT protein sequence with that of other species shows that arginine at codon 233 is highly conserved. ${ }^{21}$ The fact that the two independent mutations C819T and G820A affect this particular amino acid in patients with $\mathrm{PH} 1$ suggests that this region is of major importance in the protein. The isoleucine residue at 244 which is changed to threonine by the more frequent T853C mutation is only conserved between humans and rats. The fourth mutation, G860A, leads to a stop codon at $\operatorname{Trp} 246$, which potentially generates a truncated protein without the carboxy-terminal 146 amino acids and without the peroxisomal targeting sequence.

At present, our understanding of the effect of these four mutations on the enzyme is limited. In 11 of 12 patients on whom tissue analysis was performed, the biochemical phenotype was very similar. The mutations in exon 7 could be surmised to influence mRNA or protein stability. Unfortunately, direct assessment of RNA was not possible in these cases as hepatocyte mRNA was not available. Thus, final proof of the effect of these mutations requires in vitro expression of the mutant protein. Such a system will also allow study of the effect, if any, of the newly recognised C1342A polymorphism in the 3' untranslated region of exon 11. This polymorphism occurred with a similar allelic frequency in $\mathrm{PH} 1$ patients and controls, but unlike the other polymorphisms defined in AGXT was not associated with the minor allele.- Polymorphisms in the 3 ' untranslated region have been shown to influence gene expression as described for the vitamin D receptor gene $\mathrm{e}^{22}$ and therefore $\mathrm{C} 1342 \mathrm{~A}$ warrants further investigation.

We are grateful to many clinicians from a variety of countries for providing samples from $\mathrm{PH} 1$ patients. This project was providing samples from PHo patient. Thi project was and the Sir Jules Thorn Charitable Trust (GR)

1 Danpure CJ, Jennings PR. Peroxisomal alanine:glyoxylate aminotransferase deficiency in primary hyperoxaluria type 1. FEBS Lett 1986;201:20-4.

2 Purdue PE Lumb MJ, Fox $M$, et al. Characterization and chromosomal mapping of a genomic clone encoding human alanine:glyoxylate aminotransferase. Genomics human alanine

3 Danpure CJ, Jennings PR, Fryer P, Purdue PE, Allsop J. Primary hyperoxaluria type 1: genotypic and phenotypic heterogeneity F Inherit Metab Dis 1994;17:487-99.

4 Latta K, Brodehl J. Primary hyperoxaluria type I. Eur 7 Pediatr 1990;149:518-22.
5 Watts RW, Calne RY, Rolles K, et al. Successful treatment of primary hyperoxaluria type I by combined hepatic and primary hyperoxaluria type 1 by combined

6 Danpure CJ, Rumsby G. Enzymology and molecular genetics of primary hyperoxaluria type 1 . Consequences fo clinical management. In: Khan SR, ed. Calcium oxalate in biological systems. Boca Raton: CRC Press, 1995:189-205.

7 Purdue PE, Takada Y, Danpure CJ. Identification of mutations associated with peroxisome-to-mitochondrion mis-
targeting of alanine/glyoxylate aminotransferase in primary hyperoxaluria type 1. F Cell Biol 1990;111:2341-51.

8 Purdue PE, Lumb MJ, Allsop J, Danpure CJ. An intronic duplication in the alanine:glyoxylate aminotransferase gene facilitates identification of mutations in compound heterozygote patients with primary hyperoxaluria type 1. Hum zygote patients with

9 Danpure CJ, Birdsey GM, Rumsby G, et al. Molecular characterization and clinical use of a polymorphic tandem repeat in an intron of the human alanine:glyoxylat aminotransferase gene. Hum Genet 1994;94:55-64.

10 Nishiyama K, Funai $T$, Katafuchi $\mathrm{R}$, et al. Primar hyperoxaluria type I due to a point mutation of $T$ to $C$ in the coding region of the serine:pyruvate aminotransferase gene. Biochem Biophys Res Commun 1991;176:1093-9.

11 Minatogawa Y, Tone S, Allsop J, et al. A serine-tophenylalanine substitution leads to loss of alanine: glyoxylate aminotransferase catalytic activity and immunoreactivity in a patient with primary hyperoxaluria type 1. reactivity in a patient with prim

12 Purdue PE, Lumb MJ, Allsop J, Minatogawa Y, Danpure CJ. A glycine-to-glutamate substitution abolishes alanine: glyoxylate aminotransferase catalytic activity in a subset of patients with primary hyperoxaluria type 1. Genomics 1992 13:215-18.

13 Danpure CJ, Purdue PE, Fryer P, et al. Enzymological and mutational analysis of a complex primary hyperoxaluria type 1 phenotype involving alanine:glyoxylate aminotransferase peroxisome-to-mitochondrion mistargeting and inferase peroxisome-to-mitochondrion mistargeting and in32 .

14 Higuchi R. Simple and rapid preparation of samples for PCR. In: Erlich HA, ed. PCR-technology. New York: Stockton Press, 1989:31-8.

15 Whittall R, Gudnason V, Weavind GP, et al. Utilities for high throughput use of the single strand conformational polymorphism method: screening of 791 patients with familial hypercholesterolaemia for mutations in exon 3 of the low density lipoprotein receptor gene. $f$ Med Genet 1995;32:509-15.

16 Sanger F, Nicklen S, Coulson AR. DNA sequencing with chain-terminating inhibitors. Proc Natl Acad $S_{c i}$ US 1977;74:5463-7.

17 Rumsby G, Weir T, Samuell CT. A semiautomated alanineglyoxylate aminotransferase assay for the tissue diagnosis of primary hyperoxaluria type 1. Ann Clin Biochem (in press)

18 Sheffield VC, Beck JS, Kwitek AE, Sandstrom DW, Ston EM. The sensitivity of single-strand conformation polymorphism analysis for the detection of single base substitutions. Genomics 1993;16:325-32.

19 Motley A, Lumb MJ, Oatey PB, et al. Mammalian alanine/glyoxylate aminotransferase 1 is imported into peralanine/glyoxylate aminotransferase 1 is imported into peroxisomes via the PTS1 translocation pathway. Increased PTS1 motif and implications for the peroxisome-toPTS1 motif and implications for the peroxisome-tomitochondrion mistargeting of AGT in p
oxaluria type 1. 7 Cell Biol 1995;131:95-109.

20 Oda T, Miyajima H, Suzuki Y, Ichiyama A. Nucleotide sequence of the cDNA encoding the precursor for mitochondrial serine:pyruvate aminotransferase of rat liver. Eur F Biochem 1987;168:537-42.

21 Lumb MJ, Purdue PE, Danpure CJ. Molecular evolution of alanine/glyoxylate aminotransferase 1 intracellular targeting. Analysis of the feline gene. Eur $\mathcal{F}$ Biochem 1994;221:53 62 .

22 Morrison NA, Qi JC, Tokita A, et al. Prediction of bone density from vitamin D receptor alleles. Nature $1994 ; 367$ 284-7. 